\title{
MEMBANGUN SERVER HOTSPOT BERBASIS MIKROTIK DI SMAN 1 PRAYA TENGAH
}

Muhamad Hariadi ${ }^{1}$, Wire Bagye ${ }^{2}$, Mohammad Taufan Asri Zaen ${ }^{3}$

1, 2,3, Tehnik Informatika, STMIK Lombok

Jln. Basuki Rahmat No.105 Praya Lombok Tengah Telp. (0370) 654310, 653109 Fak. (0370) 653109

1mhariadi76@gmail.com, ̌ㅜirestmik@gmail.com, ${ }^{3}$ opanzain@gmail.com

\begin{abstract}
Development of information technology, supporting equipment computer network is still very necessary. The equipment also has become an important component in the development of computer networks. Network is the hardware and software in a system that has a specific rule that governs all the activities and behavior of its members in the smooth conduct learning activities in SMAN 1 Praya Tengah to the Internet network in need of proper management of information flow

This study covers how to build server-based hotspot mikrotik in SMAN 1 Praya Tengah with NDLC methodology, analysis and design stage using modeling analysis methodology PIECES by using Winbox, while the design of the development and implementation of network simulation method GNS3

Internet network connection test results conducted user shows the implementation of the design mikrotik in SMAN 1 Praya Tengah, sharing bandwidth with mikrotik internet provides convenience and practicality in the use of internet
\end{abstract}

Keywords : Mikrotik, Hotspot, Network Computer

\section{ABSTRAK}

Sejalan dengan perkembangan teknologi informasi, peralatan pendukung jaringan komputer masih sangat diperlukan. Peralatan juga telah menjadi komponen penting dalam pengembangan jaringan komputer. Jaringan adalah perangkat keras dan perangkat lunak dalam suatu sistem yang memiliki aturan khusus yang mengatur semua kegiatan dan perilaku anggotanya dalam kelancaran kegiatan pembelajaran di SMAN 1 Praya Tengah ke jaringan internet yang membutuhkan pengelolaan aliran informasi yang tepat

Penelitian ini mencakup bagaimana membangun mikrotik hotspot berbasis server di SMAN 1 Praya Tengah dengan metodologi NDLC, analisis dan tahap desain menggunakan metodologi analisis pemodelan PIECES dengan menggunakan Winbox, sedangkan desain pengembangan dan implementasi metode simulasi jaringan GNS3

Hasil tes koneksi jaringan internet yang dilakukan pengguna menunjukkan implementasi desain mikrotik di SMAN 1 Praya Tengah, berbagi bandwidth dengan mikrotik internet memberikan kemudahan dan kepraktisan dalam penggunaan internet

kata kunci : Mikrotik, Hotspot, Network Computer

\section{PENDAHULUAN}

Teknologi informasi dan komunikasi sekarang ini sudah menjadi bagian yang tidak terpisahkan dari berbagai bidang, perubahan globalisasi menjadi tidak bisa dihindarkan oleh setiap orang. Teknologi telah mendorong terjadinya perubahan, kompetisi yang tinggi dan tuntutan para pengguna internet yang semakin meningkat. Teknologi menjadi bagian yang tidak terpisahkan dari berbagai bidang kehidupan seperti pemerintahan dengan e-goverment, ekonomi dengan e-business, pendidikan dengan e-learning, dan bidang lainnya yang tergantung dengan teknologi informasi dan komunikasi [8].

Tuntutan untuk pintar dan bijaksana memanfaatkan jaringan sebagai alat telekomunikasi menjadi dibutuhkan misalnya, pada beberapa sekolah sudah mulai merasakan kelancaran belajar dengan jaringan internet sehingga dibutuhkan pengelolaan arus informasi yang tepat, pengaturan bandwidth dan user yang terdapat pada mikrotik (bandwidth managment 
dan user managment) menjadi penting agar pengguna internet merasa nyaman dan dapat pemakaian sesuai kebutuhan. SMA Negeri 1 Praya Tengah dengan fasilitas laboratorium komputer yang cukup mendukung akan tetapi belumnya terkoordinir fasilitas internet mengakibatkan terkadang koneksi internet terputus atau lemah. Maka, perlu memperhatikan layanan bandwidth internet dengan baik sebab kapasitas bandwidth yang besar dan mahal menjadi beban permasalahan bagi beberapa instansi khususnya sekolah. Sehingga, penting rasanya pengelolaan, pengaturan kapasitas bandwidth maupun pengguna dioptimalkan untuk melayani pengguna internet secara bersamaan seperti guru dan siswa. Sebaliknya, pengaturan bandwidth yang tidak tepat akan mengakibatkan traffic dan bandwidth full di saat para penggunanya tidak terkontrol.

Sisi lain, masalah yang sering muncul di instansi khususnya sekolah adalah tidak terbatasnya status pengguna akses atas koneksi internet. Sedangkan, Siswa-siswi dan guru SMAN 1 Praya Tengah yang mengakses tidak dibatasi dan terkontrol akan berdampak munculnya permasalahan koneksi internet yang lemah. Prihatinnya, guru atau siswa tidak lagi konsentrasi terhadap esensi kebermanfaatan internet atau pendidikan. Gambaran persoalan tersebut, sehingga penting membangun server hotspot berbasis mikrotik.

Model Network Development Life Cycle (NDLC) adalah metode yang tepat digunakan pada server hotspot berbasis mikrotik. NDLC merupakan model yang mendefinisikan siklus proses perancangan atau pengembangan suatu sistem jaringan komputer khususnya pada internet. Terdiri dari beberapa fase, tahapan, langkah atau mekanisme proses spesifik dan menggambarkan siklus yang awal dan akhirnya dalam membangun sebuah jaringan komputer. Berdasarkan permasalahan tersebut, maka penulis tertarik meneliti "Membangun Server Hotspot Berbasis Mikrotik di SMA Negeri 1 Praya Tengah".

\section{PUSTAKA DAN TEORI}

\section{A. Tinjauan Pustaka}

Implementasi jaringan hotspot di STMIK Pradnya Paramita Malang masih mengalami masalah dalam keamanan jaringan. Serangan keamanan jaringan yang sering dan mengganggu yang menyerang Mac Clone. Mengganggu dan memperumit masalah karyawan serta siswa yang memiliki hak akses secara hukum karena hak akses digandakan oleh pengguna yang tidak bertanggung jawab. untuk mengatasi masalah ini dibangun keamanan jaringan dengan pengaturan firewall yang disaring aturan dan NAT. Berdasarkan hasil pengujian disimpulkan bahwa dalam membangun keamanan jaringan hotspot RouterOS menggunakan 5.18 untuk meninggalkan pengaturan pada firewall, dapat mengatasi serangan Mac Clone yang ada pada STMIK Pradnya Paramita Malang[1].

Implementasi MikroTik RouterOS TM sistem operasi Linux dasar yang dimaksudkan sebagai router jaringan untuk memberikan kenyamanan bagi pengguna. Administrasi dapat dilakukan melalui Aplikasi Windows (Winbox). Selain instalasi dapat dilakukan pada PC Standar (Personal Computer). PC yang akan digunakan sebagai router proksi tidak memerlukan sumber daya yang substansial untuk penggunaan standar, misalnya, hanya sebagai gateway. Untuk keperluan beban besar (jaringan yang kompleks, rute rumit) disarankan untuk mempertimbangkan pemilihan sumber daya PC yang memadai. hasil pengujian dapat menunjukkan Sistem penagihan yang dapat mengatur dan membatasi klien untuk menggunakan akses internet. Sistem ini memberikan dampak saling menguntungkan antar semua pengguna [2].

Upaya peningkatan keamanan dan kenyamanan pengguna internet dilakukan dengan autentifikasi yang menggunakan username dan password untuk mengakses layanan hotspot. Implentasi hotspot dengan menggunakan username dan password membutuhkan aplikasi pendukung RADIUS dan sistem portal captative sebagai media autentifikasi dan autorisasi data pengguna dan mengarahkan pengguna ke halaman autentifikasi akses hotspot. Pada penelitian ini digunakan metode deskriftif dengan menganalisa data-data dan menggunakan data tersebut sebagai acuan pembangunan sistem. dikembangkan aplikasi berbasis web yang digunakan pengguna hotspot untuk melakukan pendaftaran dan pengelola hotspot untuk melakukan verifikasi. Hasil penelitian yang berupa aplikasi pendaftaran dan manajemen pengguna hotspot menjadi solusi mengatasi permasalah pengelolaan layanan hotspot yang menerapkan metode autentifikasi username dan password[3]. 
Dalam meningkatkan jumlah pelanggan, Kedai Kita menyediakan koneksi internet gratis untuk pelanggan. Toko ini hanya dikunjungi oleh sejumlah anak muda, baik pelajar SMA atau mahasiswa.Terjadi akses bandwidth yang tidak sama antar pengguna Koneksi yang tidak merata yang mengakibatkan ketimpangan pada pelanggan yang hanya memesan kopi dapat memiliki koneksi internet yang sama dengan mereka yang memesan lebih banyak makanan dengan jumlah pembayaran yang sangat jauh relative berbeda. Dengan membeli makanan atau minuman minimal Rp. 10.000, pelanggan dapat menghabiskan waktu berjam-jam untuk duduk dan saat menonton video streaming. Hasil pengamatan membuktikan bahwa pembeli berytujuan mendapatkan koneksi internet daripada belanja makanan. Upaya mengatasi hal ini ialah derngan melakukan manajemen bandwidth dan batasan waktu dibuat berdsasarkan nominal belanja. Penelitian ini menggunakan metode Network Development Life Cycle (NDLC). Hasil penelitian pelanggan akan mendapatkan bandwidth koneksi berdasarkan jumlah pengeluaran menggunakan voucher[4].

Kurangnya pengelolaan Acces poit menyebabkam penggunaanya tidak optimal dalam menyebarkan koneksi jaringan wireless. Upaya peningkatan jangkauan dan kemanan jaringan wireless harus dioptimalkan untuk mengurangi batasanjangkaian dan kwalitas layanan permasalahan yang terjadi ialah semakin banyak wireless dan access point serta banyaknya user yang terkoneksi yang tidak dikelola dengan baik dan secara optimal. Upya optimalisasi dilakukan dengan mengimplementasikan Controller Access Point System Management (CAPsMAN). Hasil penelitian ini ialah access point dapat mengelola banyak user yang terhubung dalam bersamaan[5].

Penelitian ini mengimplementasikan sebuah hotspot mikrotik dengan sistem login untuk pengguna siswa, guru maupun karyawan; dan membangun sebuah sistem manajemen user pada hotspot sehingga administrator jaringan dapat mengontrol dan memonitoring user dan lubang keamanan bisa tertutupi. Hasil uji coba menunjukkan bahwa sejumlah pengguna mendapat batsan paket bandwidth sesuai dengan paket yang didapat [6].

\section{B. Mikrotik}

Mikrotik adalah sistem operasi dan perangkat lunak yang dapat digunakan untuk menjadikan komputer manjadi router network yang handal, mencakup berbagai fitur yang dibuat untuk ip network dan jaringan wireless.

Mikrotik dibuat oleh Mikrotikls sebuah perusahaan di kota Riga, Latvia. Latvia adalah sebuah Negara yang merupakan pecahan dari Negara Uni Soviet dulunya atau Rusia sekarang ini. Mikrotik, merupakan sistem operasi Linux Base yang diperuntukkan sebagai network router. Didesain untuk memberikan kemudahan bagi penggunanya. Administrasinya bisa dilakukan melalui Windows Application (Winbox). Selain itu instalasi dapat dilakukan pada standard komputer PC (Personal Computer).

\section{Firewall}

Sebuah sistem atau perangkat yang mengizinkan lalu lintas jaringan yang dianggap aman untuk melaluinya dan mencegah lalu lintas jaringan yang tidak aman. Umumnya, sebuah firewall diimplementasikan dalam sebuah mesin terdedikasi, yang berjalan pada pintu gerbang (gateway) antara jaringan lokal dan jaringan lainnya. Firewall umumnya juga digunakan untuk mengontrol akses terhadap siapa saja yang memiliki akses terhadap jaringan pribadi dari pihak luar.

Bandwidth sering digunakan sebagai suatu sinonim untuk data transfer rate yaitu jumlah data yang dapat dibawa dari sebuah titik ke titik lain dalam jangka waktu tertentu (pada umumnya dalam detik). Jenis Bandwidth ini biasanya diukur dalam bps (bits per second). Proxy adalah sebuah komputer server atau program komputer yang dapat bertindak sebagai komputer lainnya untuk melakukan request terhadap content dari internet atau intranet. Proxy juga dapat digunakan untuk mengamankan jaringan pribadi yang dihubungkan ke sebuah jaringan publik. Proxy server memiliki lebih banyak fungsi daripada router yang memiliki packet filtering karena proxy server beroperasi pada level yang lebih tinggi dan memiliki kontrol yang lebih menyeluruh terhadap akses jaringan.

\section{Winbox}

Winbox adalah sebuah utility yang di gunakan untuk melakukan remote ke server mikrotik dalam mode GUI (Graphical User 
Interface). Dengan menggunakan winbox maka pengguna melakukan setting dengan melakukan klik tanpa script.

\section{METODOLOGI PENELITIAN}

A. Pengumpulan Data

1. Observasi dengan mengadakan pengamatan langsung pada sistem jaringan yang ada pada SMA Negeri 1 Praya Tengah dan mencatat hasil dari pengamatan tersebut.

2. Wawancara cara tanya jawab antara peneliti dengan informan atau subjek penelitian. Melalui metode wawancara, peneliti melakukan tanya jawab secara langsung kepada pihak yang terlibat untuk mendapatkan informasi yang berhubungan dengan pengelola jaringan SMA Negeri 1 Praya Tengah dan mencatat hasil dari wawancara tersebut.

3. Studi Kepustakaan dengan menelusuri penelitian terdahulu, teori terkait penelitian, dan metode terbaru terkait penelitian implementasi hotspot.

\section{B. Analisis}

Adapun cara metode mengambil data dalam penelitian yakni penulis menggunakan pendekatan terhadap model Network Development Life Cycle (NDLC) dapat di gambarkan di dalam diagram berikut :

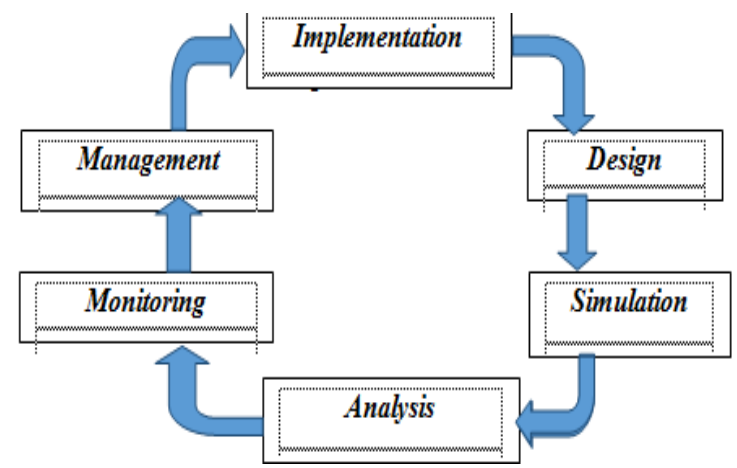

Gambar 3.1 Flow Network Development Life Cycle (NDLC)

NDLC merupakan model yang mendefinisikan siklus proses perancangan atau pengembangan suatu sistem jaringan komputer. NDLC mempunyai elemen yang mendefinisikan fase, tahapan, langkah atau mekanisme proses spesifik. Kata Cycle merupakan kunci deskriptif dari siklus hidup pengembangan sistem jaringan yang menggambarkan secara keseluruhan proses dan tahapan pengembangan sistem jaringan yang berkesinambungan.NDLC adalah metode yang digunakan sebagai acuan (secara keseluruhan atau secara garis besar) pada proses pengembangan dan perancangan system jaringan komputer. Metode perancangan yang penulis gunakan adalah Network Development

\section{Perancangan Jaringan}

Perancangan dapat dijelaskan bahwa yang menjadi pusat dari jaringan yang dirancang di SMAN 1 Praya Tengah perangkat mikrotik router board yang akan difungsikan sebagai router, gateway, radius server, hotspot server, proxy server, pemberian IP pada mikrotik routerboard dilakukan secara static, perancangan mikrotik di SMAN 1 Praya Tengah dapat di jelaskan bahwa perangkat keras yang di butuhkan yaitu routerboard, Wireless Access Point, Switch, PC Client, tablet, smartphone dan notebook routerboard merupakan device yang digunakan untuk me-routing jaringan dengan sistem operasi mikrotik. Tahap pertama yaitu menghubungkan modem ISP (Internet Service Provider) ke mikrotik, kemudian menghubungkan access point dan switch langsung terhubungan dengan router mikotik. Jadi koneksi internet yang ada di SMAN 1 Praya Tengah dihubungkan dan diatur dalam router mikrotik seperti pada gambar di bawah ini.

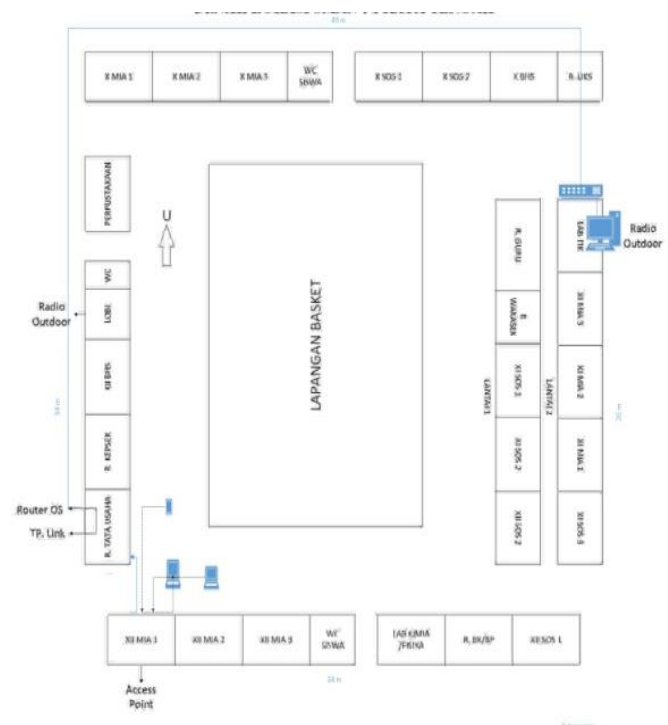

\section{Gambar 3.2 Rancangan Topologi jaringan} Mikrotik

Gambar 3.2 menjelaskan jumlah komputer yang di gunakan di Lab.Komputer pada SMAN I Praya Tengah adalah 60 unit, dan cara pemakaian pada siswa menggunakan per kelas 
pada setiap mata pelajaran TIK,adapun jumlah siswa per kelas antara 28 sampai 35.

\section{Analisa Kebutuhan}

Beberapa alat yang dibutuhkan untuk analisis jaringan server hostpot sebagai berikut

1. Microsoft visio professional 2013, software yang digunakan untuk menggambarkan desain arsitektur jaringan.

2. winbox loader v3.0rc12, digunakan untuk meremote dan mengkonfigurasi Mikrotik RouterOS

3. PIECES, digunakan untuk mensimulasikan system yang berjalan

\section{E. Analisis User}

Analisis User dimaksudkan untuk mengetahui siapa saja user yang terlibat dalam penggunaan internet di sekolah. Sehingga dapat diketahui tingkat efektifitas jaringan dan pemahaman user terhadap komputer. di SMA Negeri 1 Praya Tengah terdapat tiga jenis user yaitu staf guru (42 orang), pegawai tatausaha (16 orang) dan siswa sebanyak 588.

\section{F. Perancangan}

Perancangan manajemen bandwidth menggunakan bantuan aplikasi Winbox dengan cara meremot dan mengkonfigurasikan Mikrotik RouterOS. Program ini masih menggunakan alat bantu administrator untuk memper mudah menjalankan, mengelola atau mengatur bandwidth tiap client yang semula dengan mengetikkan perintah-perintah di konsol untuk mengelola, menjalankan atau mengatur bandwidth. Skenario rancangan untuk menentukan pembatasan bandwidth pada setiap client.

Untuk mengelola bandwidth dengan metode Network Development Life Cycle (NDLC). Konfigurasi untuk membatasi bandwidth pada mikrotik yaitu, melakukan konfigurasi interface yang akan digunakan modem usb untuk mendial internet lewat router mikrotik, Kemudian konfigurasi brigde yang berfungsi menggabungkan 2 atau lebih interface yang bertipe ethernet, atau sejenisnya, selanjutnya pemberian IP address sesuai dengan konfigurasi interface. Kemudain selanjutnya konfigurasi routing menggunakan OSPF yang berfungsi membagi-bagi jaringan menjadi beberapa tingkat, dan yang terakhir mengaktifkan hotspot agar komputer lainnya bisa terhubung ke mikrotik serta konfigurasi security profile untuk setting nama jaringan, authentication types (WPA PSK,WPA2 PSK, WPA EAP, dan WPA2 EAP) dan password.

\section{G. Simulasi}

Pada tahap simulasi ini, simulation prototyping dilakukan. Hal ini dimaksudkan untuk melihat kinerja awal dari jaringan yang dibangun. Simuylasi dijalankan pada aplikasi GNS3.

\section{IMPLEMENTASI DAN PEMBAHASAN}

\section{A. konsfigurasi}

Perangkat keras yang dibutuhkan yaitu router board, Wireless Access Point, Switch, PC Client, dan notebook. Router board merupakan device yang digunakan untuk me-routing jaringan dengan sistem operasi mikrotik. Tahap pertama yaitu menghubungkan modem ISP (Internet Service Provider) ke mikrotik, kemudian menghubungkan access point dan switch utama langsung berhubungan dengan router mikotik. Jadi, koneksi internet yang ada di SMA Negeri 1 Praya Tengah ini, dihubungkan dan diatur dalam router mikrotik, sedangkan untuk manajemen jaringan diatur dengan menjalankan aplikasi winbox pada $P C$ client. pada tahapan implementasi perangkat lunak, dibutuhkan aplikasi winbox, web browser, dan sistem operasi mikrotik. Dengan menggunakan routerboard, maka sistem operasi mikrotik sudah terinstal didalamnya.

Konfigurasi awal mikrotik dilakukan dengan aplikasi winbox. Sedangkan web browser dapat digunakan untuk konfigurasi mikrotik setelah melakukan konfigurasi awal dengan winbox.

1. Instalkan Software Winbox pada komputer

2. Buka aplikasi winbox yang sudah terinstal tadi dengan klik 2 kali pada dekstop Berikut adalah tampilan Software Winbox v3.0rc12. 


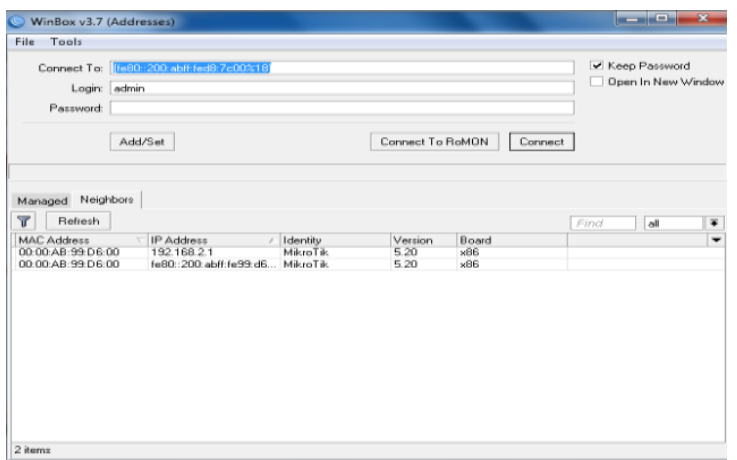

Gambar 4.1 Tampilan Winbox v3.Orc12.

3. Menghubungkan kabel Unshilded Twisted Pair (UTP) pada port1/ethernet1 di mikrotik dan di hubungkan ke modem

4. Kemudian tekan tomol refresh pada tombol winbox kemudian pilih 'MACAddress" sebelumnya modem di seting dengan menggunakan setingan static yang berarti kita akan menulis sendiri ip internet yang diberikan modem 192.168.1.1/24 ke router 192.168.1.2/24. Kemudian pilih Connect.

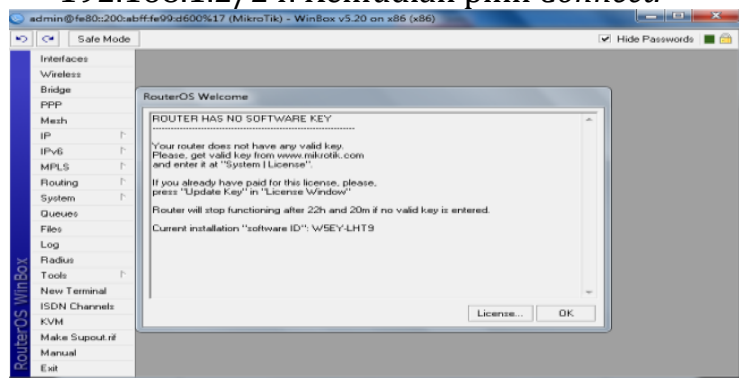

Gambar 4.2 winbox windows loader v3.Orc12

5. Tampilan Mikrotik Router setelah mengguankan software mikrotik winbox loader v3.Orc12.

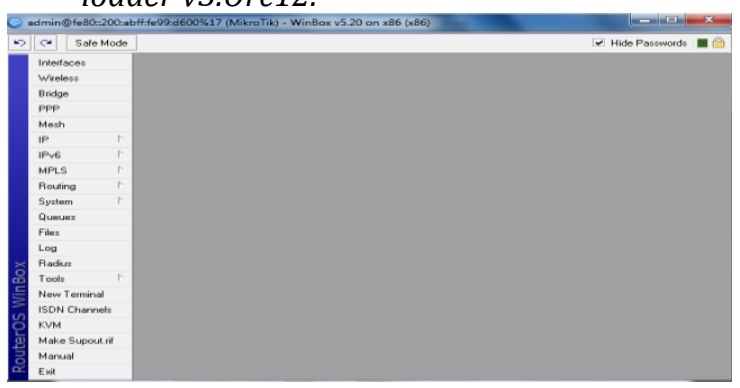

Gambar 4.3 Mikrotik winbox windows loader v3.Orc12

\section{B. Implementasi Jaringan}

Untuk mengkonfigurasi hotspot pada mikrotik, tahapan awal yang harus dilakukan adalah mengkonfigurasi Wireless Accespoint terlebih dahulu kemudian menghubungkan wireless acccespoint ke perangkat mikrotik.
Dilanjutkan dengan mengkonfigurasi hotspot pada mikrotik.

1. Konfigurasi wireless accesspoint Langkah-langkah dalam setting acces point yang dilakukan sebagai berikut:

Tampilan awal koneksi system wirreless acces point dengan ip default 192.168.1.254 dimana tampilan tersebut dibuka melalui "Web Browser" kemudian masukan ip default "Acces Point"

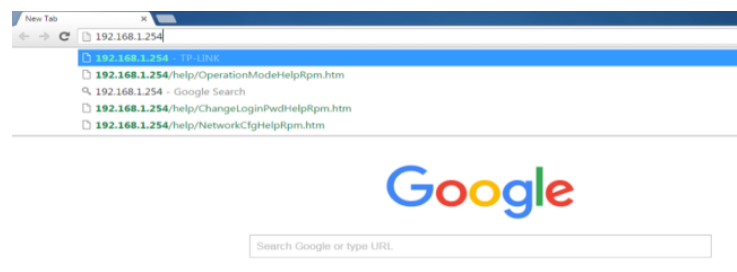

Gambar 4.4. Masuk kedalam system acces point

2. Pada tampilan utama TP LINK. Pada bagian sub menu operation mode pilih AP (Acces Point) kemudian klik "Save"

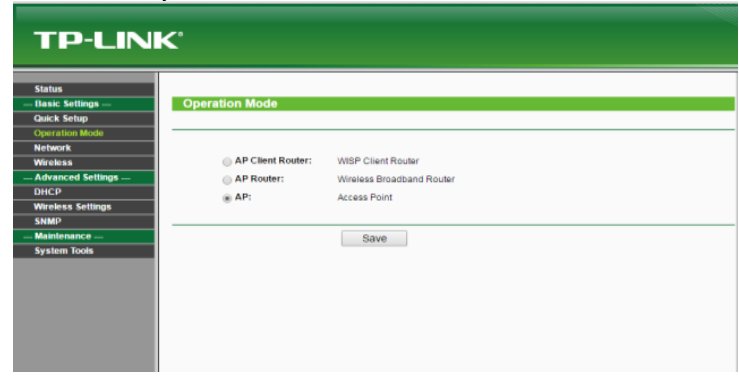

Gambar 4.5. Tampilan utama access point TPLINK

Tahap ini merupakan tahapan yang dilakukan oleh penulis dalam melakukan uji coba dan hasil dari perangkat yang diterapkan pada obyek penelitian, baik itu uji coba dari sisi server maupun dari sisi client perangkat pengembangan system jaringan yang sudah diterapkan pada obyek yang sebenarnya.

\section{Hasil}

Adapun hasil penelitian di bawah ini akan dijelaskan berdasarkan temuan di lapangan seperti, hasil konfigurasi perangkat yang telah dilakukan oleh peneliti pada obyek penelitian, beberapa gambar yang merupakan hasil konfigurasi perangkat untuk mikrotik.Adapun penjelasannya sebagai berikut: 
a. Interfacelist hasil konfigurasi.

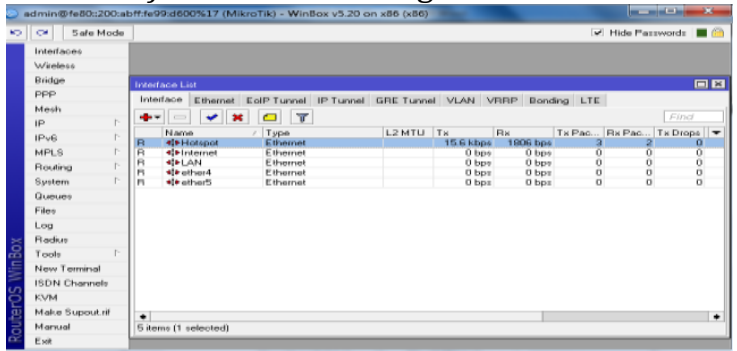

Gambar 4.6. Interface hasil konfigurasi

b. IP Address hasil konfigurasi

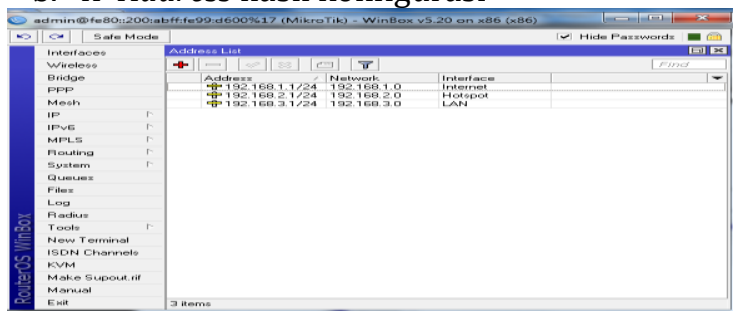

Gambar 4.7. IP Address Hasil Konfigurasi

c. NAT (Network Address Translitetation) hasil konfigurasi

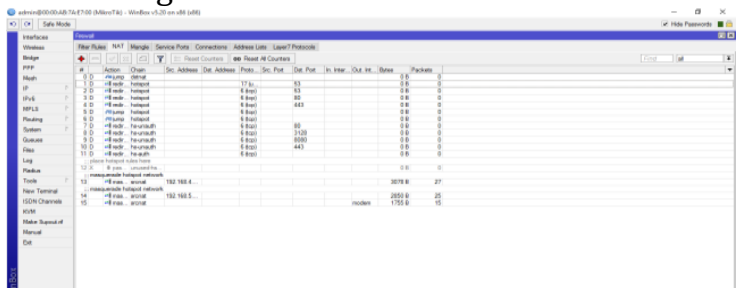

Gambar 4.8. NAT Hasil Konfigurasi

d. Router list hasil konfigurasi

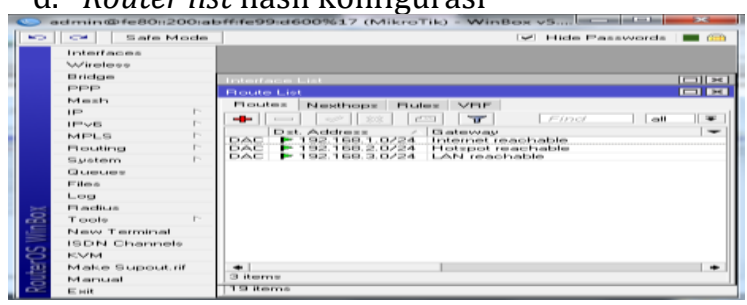

Gambar 4.9. Router Hasil Konfigurasi

e. DHCP Server hasil konfigurasi

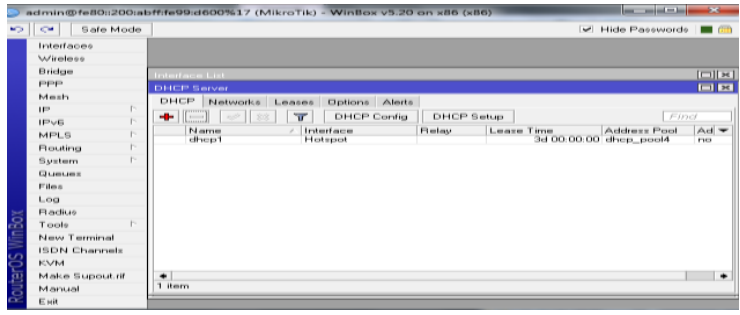

Gambar 4.510. DHCP Server Hasil Konfigurasi f. Mikrotik hotspot hasil konfigurasi

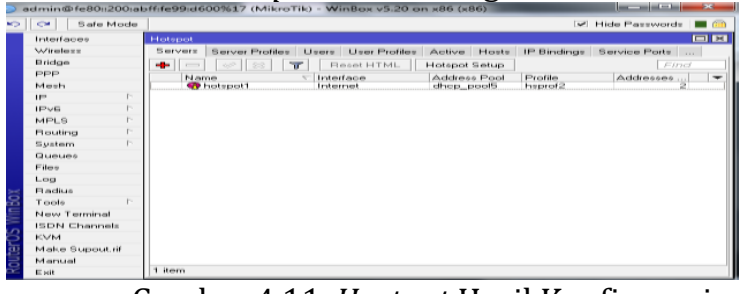

Gambar 4.11. Hostpot Hasil Konfigurasi

\section{Pengujian}

Tahap pembahasan ini merupakan tahap yang dilakukan penulis di dalam melakukan uji coba dan hasil dari perangkat baik itu uji coba dari sisi server maupun client, perangkat pengembangan system jaringan yang sudah di terapkan pada obyek yang sebenarnya.

Tahap pengujian ini untuk uji coba dari konfiguration Radius Server, ada beberapa uji coba yang dilakukan sebagai berikut :
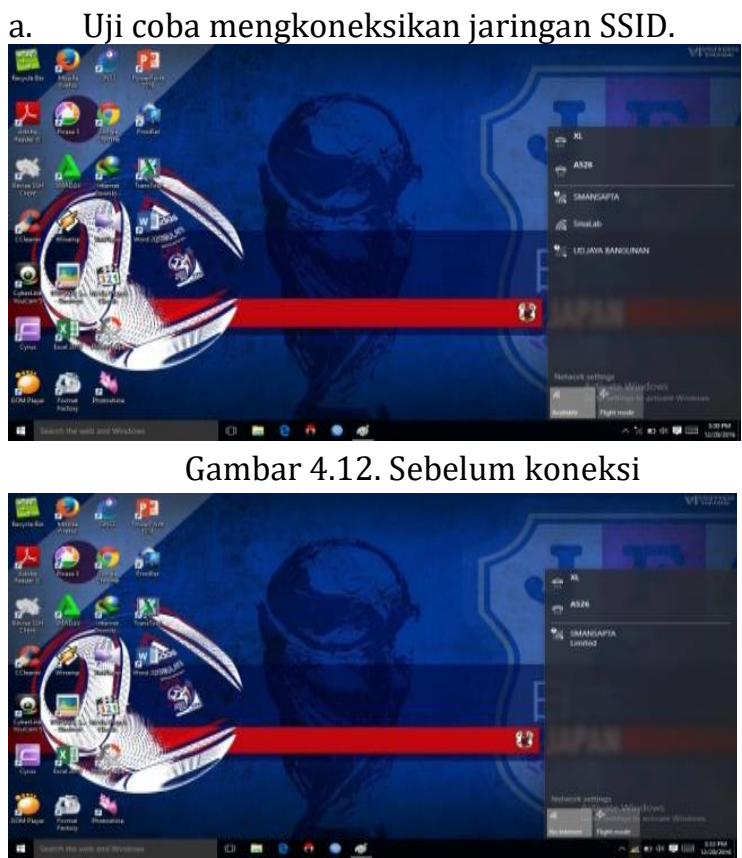

Gambar 4.13. Setelah koneksi

\subsection{Kesimpulan dan Saran}

\section{A. Kesimpulan}

Berdasarkan analisis dan perancangan system jaringan pada sekolah SMA Negeri 1 Praya Tengah, maka kesimpulannya adalah, jaringan komputer baik wireless dan kabel dapat dimanajemen dengan mikrotik, pembagian bandwidth internet maximum (1 Mbps), minimum (256 Kbps) kemudian untuk upload maxsimum dan minimum sama (128 Kbps), dengan adanya mikrotik memberikan kemudahan pemakaian internet dan sistem 
keamanan jaringan yang diberikan oleh mikrotik sehingga dapat terfasilitasi dengan baik dan untuk jaringan yang menggunakan kabel seperti komputer yang lain tetap menggunakan static IP sedangkan pada fasilitas Hotspot menggunakan IP DHCP.

\section{B. Saran}

Adapun saran yang dapat di sampaikan berdasarkan penelitian yang telah dilakukan,di antaranya adalah sebagai berikut:

1. Gunakan program GNS3 untuk latihan,karna dengan program GNS3 sistem operasi mikrotik dapat di install pada system operasi Windows,tanpa mempengaruhi system operasi windows tersebut.

2. Pada system jaringan mikrotik menyarankan penelitian lanjutan yang lebih sempurna dan dapat dilakukan kembali pada networking security hotspot adik tingkat

\section{Daftar Pustaka}

[1] Ratnasari, S. D., \& Utsalina, D. S. (2017). Implementasi Penanganan Serangan MacClone Pada Hotspot Mikrotik Di Stmik Pradnya Paramita Malang (Studi Kasus: Stmik Pradnya Paramitamalang). JURNAL TEKNOLOGI INFORMASI: Teori, Konsep, dan Implementasi, 8(1), 1-84.
[2] Putra, Ilham Eka. "Perancangan Jaringan Hotspot Berbasis Mikrotik Router OS 3.3. 0." Jurnal TeknoIf 1.1 (2013).

[3] Wicahyanto, Arif, and Estiarto Wahyu Sumirat. "Pendaftaran pengguna layanan hotspot berbasis web Pada hotspot mikrotik dan freeradius." IJNS-Indonesian Journal on Networking and Security 1.1 (2012).

[4] Husain, Husain, et al. "Pengaturan Bandwidth Management dan Time Limitation Berbasis User Manajer Mikrotik." Jurnal Mantik Penusa 2.2 (2019).

[5] Rifai, Bakhtiar, and Aji Sudibyo. "MANAGEMENT WIRELESS ACCESS POINT PADA HOTSPOT SERVER MENGGUNAKAN CONTROLLER ACCESS POINT SYSTEM MANAGEMENT." Jurnal Pilar Nusa Mandiri 14.1 (2018): 111-116.

[6] Vivanda, Tabita Wahyu Eka, and Aria Indah Susanti. "Rancang Bangun Sistem Jaringan Hotspot Berbasis Manajemen User Dengan Menggunakan Userman dan Radius Server Pada Mikrotik Routerboard di SMK Negeri 1 Kemlagi." JURNAL TECNOSCIENZA 3.2 (2019): 245-260.

[7] Kalaena, L. S., \& Bagye, W. (2018). Implementasi Network Attached Storage (NAS) Menggunakan Freenas Pada STMIK Lombok. Jurnal Manajemen Informatika dan Sistem Informasi, 1(1), 6-10. 